\title{
Produksi Biogas dari Limbah Cair Kelapa Sawit dengan Menggunakan Reaktor Unggun Tetap tanpa Proses Pretreatment
}

\section{Biogas Production from Palm Oil Mill Effluent by Using Fixed Bed Reactor without Pretreatment Process}

\author{
WIHARJA, WIDIATMINI SIH WINANTI, PRASETIYADI, AMITA INDAH SITOMURNI \\ Pusat Teknologi Lingkungan, Badan Pengkajian dan Penerapan Teknologi (BPPT) \\ Gedung 820 Geostech Lt.3, Kawasan Puspiptek Serpong, Tangerang Selatan \\ Email: wiharja@bppt.go.id
}

\begin{abstract}
Palm Oil Mill Effluent (POME) resulted from the palm oil industry is a potential resource for biogas production. In this study, POME was processed by utilizing microbes in an anaerobic condition using a fixed bed reactor. This study aimed at providing alternative processing of POME into biogas at the most optimum biogas yield without any pretreatment, taking advantage of POME conditions generated from the production process at the average temperature of $55-60{ }^{\circ} \mathrm{C}$. In the anaerobic process, temperature conditions have a significant effect on bacteria's performance to degrade organic matter. In thermophilic conditions, bacteria deteriorate organic substrates more actively than in mesophilic states. This research proved that using fixed bed reactor technology to treat POME without pretreatment has generated biogas at the yield of 25.43 liters/liter of POME production. Applying this technology also demonstrated that investment and operating costs are cheaper due to having no mixing tank and fewer chemicals applications for the neutralization process.
\end{abstract}

Keywords: biogas, fixed bed reactor, POME, pretreatment, thermophilic

\begin{abstract}
ABSTRAK
Proses pengolahan POME dapat dilakukan dengan menggunakan proses fermentasi anaerobik yaitu memanfaatkan kerja bakteri anaerobik untuk memproduksi biogas. Penelitian ini bertujuan memberikan alternatif pengelolaan limbah cair pabrik kelapa sawit yang dapat menghasilkan biogas yang paling optimal tanpa melakukan pretreatment. Proses yang dipilih disesuaikan dengan kondisi panas POME yang keluar proses yaitu sekitar $55-60{ }^{\circ} \mathrm{C}$. Kondisi temperatur sangat berpengaruh nyata terhadap kinerja bakteri pendegradasi bahan organik di dalam limbah cair dalam proses anaerobik. Pada kondisi termofilik bakteri lebih aktif dibandingkan pada kondisi mesofilik. Melalui penelitian ini, dapat diketahui bahwa dengan menggunakan teknologi reaktor fixed bed untuk mengolah POME tanpa adanya pretreatment, biogas tetap dapat diperoleh dengan perolehan rata rata 25,43 liter per liter POME. Dengan menggunakan teknologi ini biaya investasi dan operasi akan lebih murah dikarenakan tidak memerlukan bak pencampur dan penggunaan bahan kimia untuk proses netralisasi.
\end{abstract}

Kata kunci: Biogas, reaktor fixed bed, POME, pretreatment, termofilik

\section{PENDAHULUAN}

\subsection{Latar Belakang}

Minyak sawit kini menjadi salah satu jenis minyak yang paling banyak dikonsumsi dan diproduksi di dunia. Berbagai aplikasi seperti sector makanan, kosmetik, produk kebersihan, dan bahkan energi menjadi pasar dari minyak yang murah, mudah diproduksi dan sangat stabil ini. Indonesia sendiri menjadi salah satu dari produsen minyak sawit dunia selain Malaysia ${ }^{(1,2)}$. Kedua negara ini secara total menghasilkan sekitar $85-90 \%$ dari total produksi minyak sawit dunia ${ }^{(3,4)}$. Pada saat ini, Indonesia adalah produsen dan eksportir minyak sawit yang terbesar di dunia ${ }^{(5,6)}$.
Dalam prosesnya, industri kelapa sawit menghasilkan beberapa residu yang dianggap sebagai limbah ${ }^{(6)}$. Limbah ini berpotensi menjadi beban pencemaran lingkungan jika tidak dikelola dengan baik. Namun, sebenarnya jika diolah secara maksimal dengan menggunakan teknologi yang tepat, limbah-limbah tersebut akan memberikan nilai lebih yang signifikan bagi industri maupun masyarakat sekitar pabrik.

Secara umum, limbah utama dari Pabrik Kelapa Sawit (PKS) terdiri atas 2 jenis yaitu limbah padat dan limbah cair. Limbah cair industri kelapa sawit yang paling utama adalah limbah cair pabrik kelapa sawit atau Palm Oil Mill Effluent (POME), sedangkan limbah padatnya terdiri atas tandan kosong, pelepah, 
batang, dan serat mesokarp. Serat mesokarp dan tandan kosong merupakan limbah yang diperoleh ketika proses produksi berlanjut, sementara pelepah dihasilkan ketika dilakukan pemangkasan pelepah. Limbah batang sawit dihasilkan ketika proses replantasi, penggantian tanaman tua dengan tanaman yang lebih muda.

POME yang dihasilkan adalah berupa cairan kental seperti lumpur berwarna kecoklatan yang merupakan suspensi koloid tinggi dan memiliki bau yang spesifik, mengandung bahan organik yang tinggi dengan $\mathrm{pH}$ rendah $^{(6)}$.

Di Indonesia, sebagian besar pengolahan POME menggunakan teknologi covered lagoon. Teknologi ini dilakukan dengan menutup kolam limbah konvensional dengan dengan bahan reinforced polypropylene sehingga berfungsi sebagai anaerobic digester. Selain covered lagoon, juga dipergunakan reaktor anaerobik menyerupai tangki (bio-digester) dengan sistem tangka berpengaduk. Dalam prosesnya, sistem bio-digester dilengkapi dengan pengolahan awal atau pretreatment.

Tujuan pretreatment pada dasarnya adalah meningkatkan digestablitas dari substrat, sehingga dapat meningkatkan laju reaksi dalam pencernaan anaerobik dan pada akhirnya meningkatkan produksi biogas. Proses pretreatment bisa berperan sebagai katalis yang mempercepat proses reaksi.

Secara teoritis, ada banyak jenis pretreatment untuk POME. Namun, tidak semua metode pretreatment dapat digunakan untuk POME secara efektif dan efisien. Untuk POME sendiri, perlakuan awal yang biasa dilakukan meliputi proses pengadukan, netralisasi $\mathrm{pH}$, dan resirkulasi untuk mencapai $\mathrm{pH}$ 6,5-7,5 karena $\mathrm{pH}$ awal POME yang bersifat asam dan berpotensi menyebabkan bakteri konsorsium produksi biogas tidak bisa tumbuh optimal. Selain itu, pretreatment juga mencakup penurunan temperatur menjadi $40-50{ }^{\circ} \mathrm{C}$ karena temperatur awal POME juga masih terlalu panas dan akan berpotensi menghambat pertumbuhan bakteri terutama jika proses akan dilakukan secara mesofilik ${ }^{(7)}$

Terdapat berbagai macam pretreatment yang dilakukan untuk mendapatkan kondisi operasi reaktor biogas yang optimal. Mulai dari teknologi yang mendasar seperti yang disebutkan sebelumnya, hingga teknologi yang sangat canggih dengan menggunakan proses ozonisasi, ultrasonik, dan gelombang microwave. Selain itu, pretreatment POME yang sudah dilakukan misalnya flokulasi, hidrolisis enzimatik, pengasaman, dan dissolved air flotation.

Namun, kendala utama dari proses pretreatment adalah besarnya biaya operasi yang harus disediakan, mulai dari proses pendinginan yang membutuhkan energi atau penambahan zat kimia.

Jika ditemukan cara konversi POME menjadi biogas tanpa pretreatment maka akan menjadi satu langkah inovasi yang signifikan dalam pengolahan limbah POME karena potensinya yang sangat besar. Untuk itulah, pada penelitian ini akan diujicobakan pengolahan POME menjadi biogas tanpa melalui pretreatment.

Berbekal pengetahuan dan pengalaman mengembangkan reaktor unggun tetap untuk konversi limbah cair tahu yang juga memiliki keasaman cukup tinggi menjadi biogas tanpa dilakukan pretreatment, akhirnya muncul hipotesis yang sama bahwa penggunaan reaktor ini bisa diberlakukan untuk POME ${ }^{(8)}$.

Dugaan bahwa untuk mengkompensasi akibat ketiadaan proses pretreatment yang sebenarnya harus dilakukan sebelum konversi biogas, dalam penelitian ini digunakan sistem reaktor unggun tetap (fixed bed) yang dikombinasikan dengan kondisi operasi termofilik. Kondisi termofilik ini yang memungkinkan adanya kondisi yang optimal meskipun tidak dilakukan penurunan temperatur di awal. Operasi kondisi termofilik sendiri memang diakui memiliki unjuk kerja produksi biogas yang lebih baik. Operasi temperatur 55 ${ }^{0} \mathrm{C}$ sudah dibuktikan banyak penelitian untuk bisa menghasilkan lebih banyak biogas dengan perolehan yang besar dibandingkan kondisi mesofilik $\left(35-37^{\circ} \mathrm{C}\right)$. Masalah atau kendala yang dihadapi reaktor termofilik pada umumnya adalah kondisi operasi yang harus dijaga stabil pada temperatur yang lebih tinggi, sehingga biaya operasi juga menjadi mahal ${ }^{(9)}$.

Namun, pada penelitian ini, dengan mempertimbangkan temperatur awal POME yang keluar dari proses dan masuk ke reaktor biogas jika tidak dilakukan pendinginan akan memungkinkan tercapainya kondisi termofilik.

Hanya saja, reaktor yang digunakan juga harus yang memiliki unjuk kerja tinggi. Oleh karena itu, dalam penelitian ini digunakan reaktor unggun tetap (fixed bed) yang memang terbukti memiliki unjuk kerja yang baik ${ }^{(8)}$. Apalagi berbekal pengalaman reaktor jenis yang sama yang digunakan untuk pengolahan limbah cair tahu yang memiliki keasaman cukup tinggi, namun berhasil dikonversi dengan baik menjadi biogas tanpa dilakukan pretreatment netralisasi.

\subsection{Tujuan}

Tujuan penelitian ini adalah melakukan uji coba metode alternatif pengelolaan limbah cair pabrik kelapa sawit POME yang dapat menghasilkan biogas yang paling optimal tanpa melakukan pretreatment, sekaligus diharapkan 
dapat meningkatkan kinerja instalasi pengolahan limbah cair pabrik kelapa sawit di Indonesia.

\section{BAHAN DAN METODE}

Bahan utama yang digunakan dalam penelitian ini adalah POME segar yang merupakan limbah dari PTPN V Sei Pagar, Riau. Sebelum melaksanakan penelitian, karakteristik POME keluaran pabrik diuji dan diperoleh hasil seperi yang ditunjukkan Tabel 1.

Tabel 1. Karakteristik POME

\begin{tabular}{clc}
\hline No. & \multicolumn{1}{c}{ Parameter } & Nilai \\
\hline 1. & pH & $3,8-4,5$ \\
\hline 2. & Temperatur $\left({ }^{\circ} \mathrm{C}\right)$ & $30-75$ \\
\hline 3. & $\begin{array}{l}\text { Minyak dan Lemak } \\
\text { (mg/L) }\end{array}$ & $200-8.600$ \\
\hline 4. & $\begin{array}{l}\text { Padatan Total } \\
\text { (mg/L) }\end{array}$ & $\begin{array}{c}11.500- \\
67.900\end{array}$ \\
\hline 5. & Padatan & $4.100-60.400$ \\
& Tersuspensi & \\
& (mg/L) & $10.300-$ \\
\hline 6. & BOD $(\mathrm{mg} / \mathrm{L})$ & 47.500 \\
\hline 7. & COD $(\mathrm{mg} / \mathrm{L})$ & $15.600-$ \\
& & 53.600 \\
\hline 8. & Total $\mathrm{P}(\mathrm{mg} / \mathrm{L})$ & $0-110$ \\
\hline 9. & Total $\mathrm{N}(\mathrm{mg} / \mathrm{L})$ & $180-1.829$ \\
\hline
\end{tabular}

Untuk mengkonversi POME ini, penelitian ini menggunakan reaktor anaerobic unggun tetap (fixed bed) bench scale yang telah dikembangkan oleh BPPT dengan kapasitas reaktor sebesar $3 \mathrm{~m}^{3}$. Lokasi kegiatan dilakukan di PTPN V Sei Pagar Riau. Pengolahan POME dengan menggunakan teknologi ini dapat dilihat pada Gambar 1.

Sistem reaktor yang ditunjukkan pada Gambar $1 \mathrm{di}$ atas memiliki beberapa komponen yang dijelaskan pada Tabel 2 .

Tabel 2. Komponen yang digunakan untuk sistem reaktor fixed bed untuk pengolahan POME tanpa pretreatment

\begin{tabular}{llll}
\hline No & Nama & Jumlah & Kapasitas \\
\hline 1 & Tangki umpan & 2 & $1 \mathrm{~m}^{3}$ \\
\hline 2 & $\begin{array}{l}\text { Pompa umpan } \\
\text { \& sirkulasi }\end{array}$ & 2 buah & $\begin{array}{l}30 \\
\text { liter/menit }\end{array}$ \\
\hline 3 & Pipa inlet & 1 paket & - \\
\hline 4 & Digester & 1 & $3 \mathrm{~m}^{3}$ \\
\hline 5 & $\begin{array}{l}\text { Pipa out let } \\
\text { effluent }\end{array}$ & 1 & \\
\hline 6 & $\begin{array}{l}\text { Bak penahan } \\
\text { gas }\end{array}$ & 1 & 150 liter \\
\hline 7 & Pipa biogas & 1 & \\
\hline 8 & $\begin{array}{l}\text { Flow meter } \\
\text { biogas }\end{array}$ & 1 & $0,16-2,5$ \\
& & $\mathrm{~m}^{3} \quad$ per \\
\hline 9 & Gasholder & 1 & $2 \mathrm{~m}^{3}$ \\
\hline
\end{tabular}

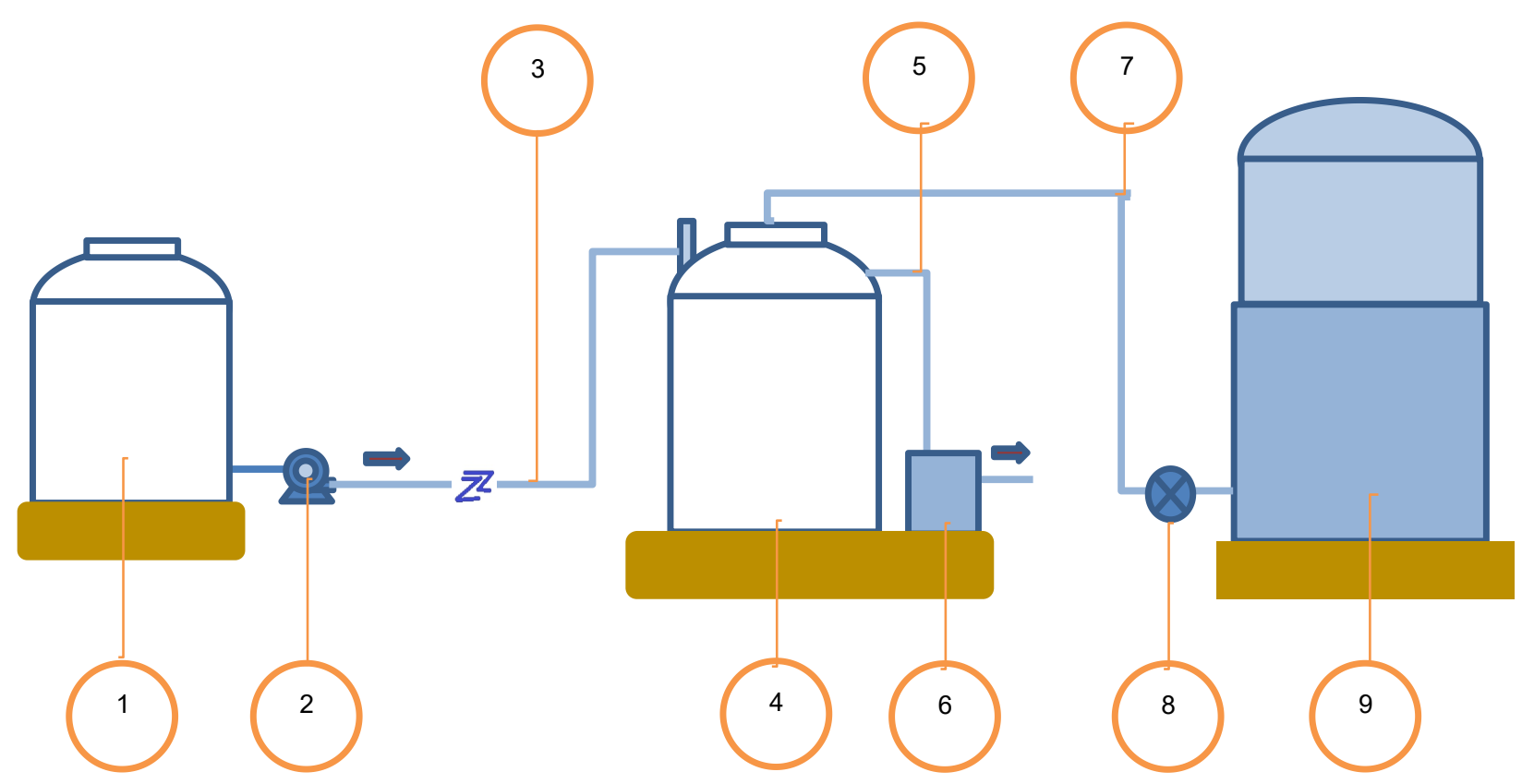

Gambar 1. Rangkaian Peralatan Pengolahan Biogas POME dengan Sistem Reaktor Fixed Bed 
Dalam penelitian ini dipergunakan kondisi sesuai dengan kondisi lingkungan yang ada sehingga harus mampu pada kondisi umpan POME panas sampai $60{ }^{\circ} \mathrm{C}$, namun di satu sisi terkadang tanpa umpan karena pabrik tidak beroperasi. POME sebagai umpan dipompa masuk ke dalam reaktor yang dioperasikan secara up flow yaitu umpan masuk melalui dasar reaktor yang kemudian didistribusikan di antara support material dan keluar melalui bagian atas. Untuk menjaga temperatur termofilik maka dilakukan sirkulasi POME bagian bawah reaktor yang dilewatkan melalui sebuah Heat Exchanger (HE).

Penelitian ini menggunakan mikroba yang terdapat dalam kotoran sapi yang diencerkan menggunakan air dengan perbandingan 1:1. Campuran air ini di samping berfungsi sebagai starter berlangsungnya proses inokulasi juga mempermudah kotoran sapi untuk dapat dipompakan dan masuk ke dalam reaktor. Pengisian reaktor dengan cairan kotoran sapi hingga mencapai volume kerjanya. Proses selanjutnya adalah inkubasi hingga terlihat adanya gas yang terbentuk yang mengindikasikan adanya bahan organik di kotoran sapi yang terdegradasi. Setelah proses inokulasi berjalan dengan baik, kemudian reaktor tersebut diadaptasikan dengan POME yang dilakukan secara kontinu dimulai dari beban organik dalam jumlah rendah hingga beban organik dengan jumlah yang tinggi. Proses adaptasi POME ini dilakukan dengan menggunakan POME yang keluar dari kolam I. Sistem aliran pada reaktor ini adalah substrat umpan masuk melalui dasar reaktor yang kemudian terdistribusi di antara material penyangga dan keluar pada bagian atas.

Produksi biogas dapat dideteksi menggunakan gas flowmeter, yang dipasang di antara reaktor dan gas holder. Dalam percobaan ini menggunakan gas flowmeter jenis basah yang hasilnya dapat langsung dibaca dari angka meter yang tercatat secara otomatis. Angka meter yang ada merupakan akumulasi dari waktu sebelumnya.

\section{HASIL DAN PEMBAHASAN}

Seperti diketahui, bahwa pembentukan biogas dan degradasi bahan organik secara anaerobik adalah sebuah proses mikrobiologi. Bibit mikroba yang baik dan murah serta banyak tersedia di sekitar kita merupakan pilihan yang utama yaitu kotoran hewan. Bakteri dalam kotoran hewan ini akan menjadi bibit dan terakumulasi. Akumulasi bakteri yang terjadi di material penyangga akan semakin banyak material organik yang dapat didegradasi. Sehingga peningkatan beban organik dapat dilakukan dengan mempertimbangkan kestabilan reaktor diantaranya $\mathrm{pH}$, produksi biogas yang dihasilkan dan persentase kandungan metan. Kondisi dikatakan stabil apabila jika dilakukan pengisian umpan, produksi gas akan bertambah, namun $\mathrm{pH}$ dan persentase biogas tidak turun.

Fermentasi anaerobik membutuhkan kondisi yang optimum, yang dapat dicapai dengan mengontrol parameter-parameter, seperti seeding atau pembibitan mikroba di dalam digester, konsentrasi influent, temperatur influent, beban bahan organik yang dimasukkan, toksisitas influent, kondisi nutrisi di dalam digester, dan keadaan lingkungan di dalam digester ${ }^{(10)}$.

Pembentukan gas metana dalam digester adalah proses biokimia yang sangat tergantung pada kontak antara limbah cair dengan mikroorganisme di dalam digester ${ }^{(11)}$. Support material dalam reaktor dapat berfungsi untuk memperbanyak jumlah bakteri di dalam reaktor ${ }^{(11,12)}$ dan akan menambah kontak antara POME dan mikroorganisme. Support material juga akan menjaga mikroorganisme agar tidak mengalami wash out ${ }^{(11)}$.

Temperatur operasi reaktor diharapkan bekerja pada temperatur $50-60{ }^{\circ} \mathrm{C}$, pada temperatur ini bakteri termofilik yang bekerja, mendegradasi bahan organik. Pemilihan ini didasarkan pada kondisi POME keluar dari pabrik masih memiliki temperatur $60-65{ }^{\circ} \mathrm{C}$ sehingga dalam perancangan sistem pengolah limbah tidak memerlukan lagi pretreatment untuk menurunkan temperatur.

Pada kenyataannya, meskipun diusahakan untuk berada pada temperatur yang stabil, namun uji coba POME tanpa pretreatment ini pernah mengalami temperatur yang cukup rendah di bawah $45{ }^{\circ} \mathrm{C}$. Hal ini terjadi karena reaktor yang dioperasikan secara batch dan cuaca saat itu hujan sehingga temperatur di dalam reaktor turun. Oleh sebab itu, perlu dilakukan pemanasan untuk menjaga proses berjalan secara termofilik. Langkah yang dilakukan adalah dengan melakukan sirkulasi POME di bagian bawah reaktor, yang kemudian diumpankan ke sebuah alat heat exchanger. Sebagai pemanas dipergunakan POME segar yang keluar dari pemisah minyak, yang masih mempunyai temperatur $60-65^{\circ} \mathrm{C}$.

Fluktuasi temperatur yang ada kemudian dikorelasikan dengan rasio produksi biogas per POME yang diinput. Hasil produksi biogas proses termofilik yang dilakukan tanpa pretreatment ini dapat dilihat pada Gambar 2. 


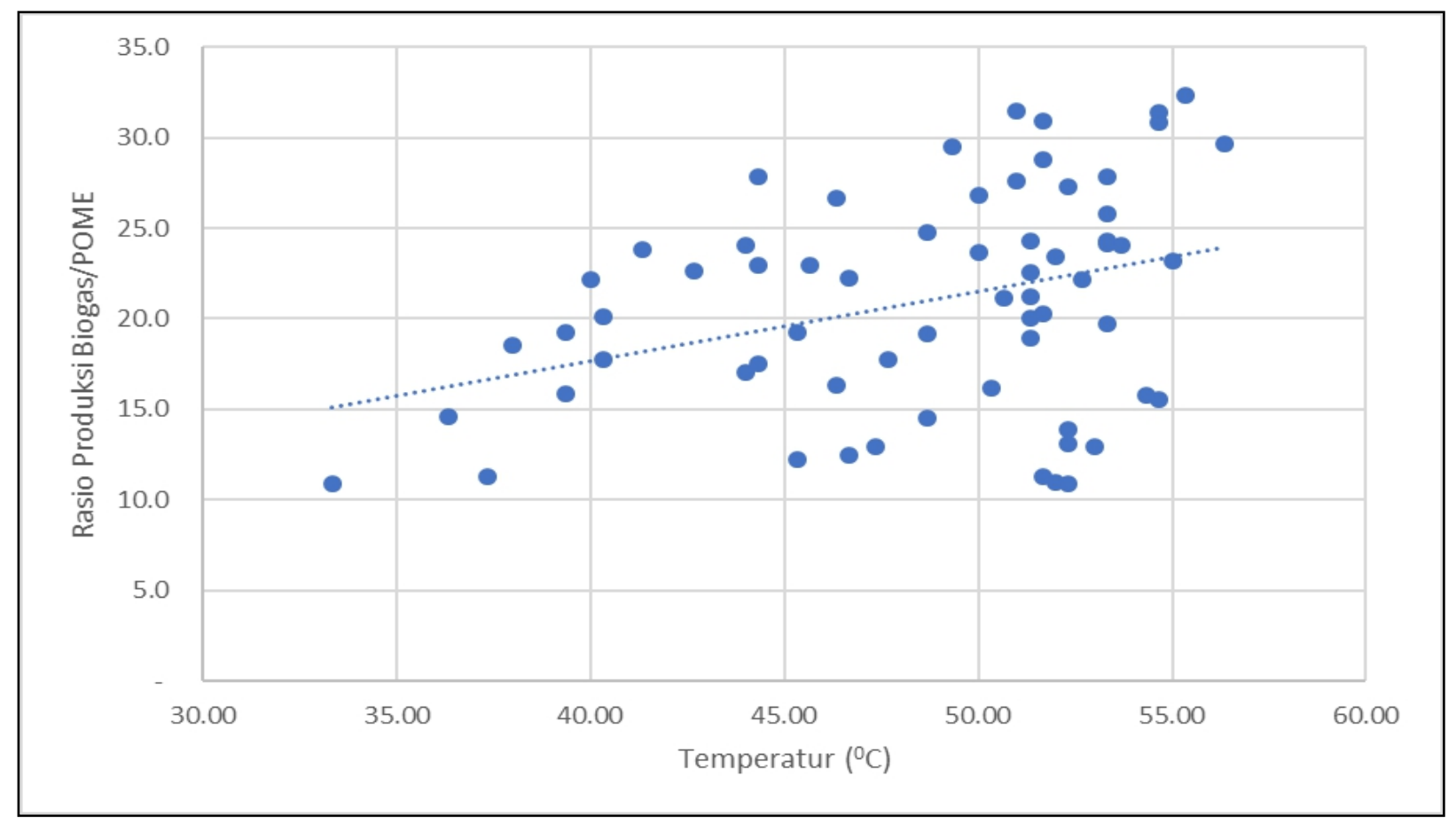

Gambar 2. Fluktuasi Temperatur Operasi Reaktor dan Rasio Produksi Biogas terhadap POME yang diinput (liter biogas/liter POME)

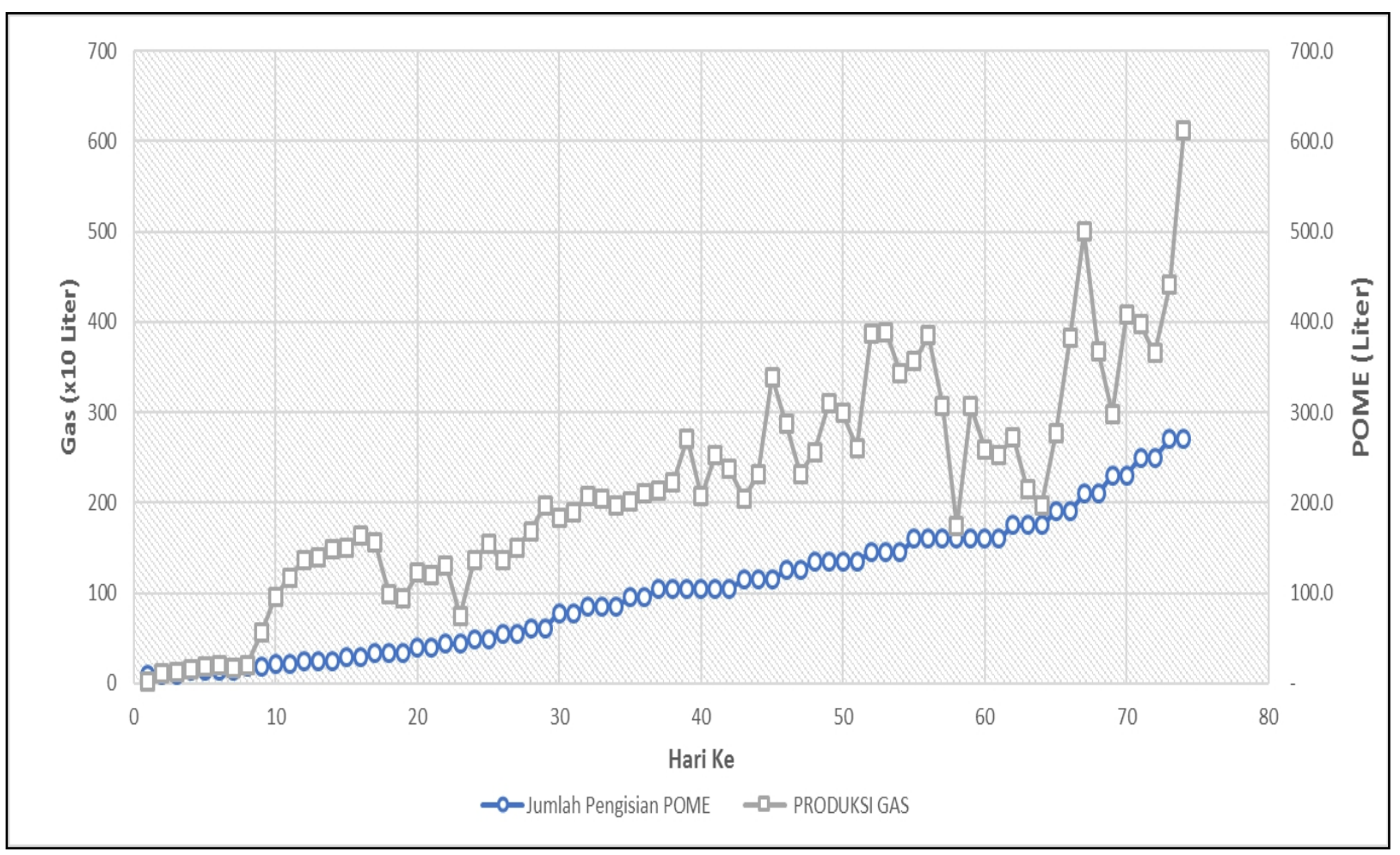

Gambar 3. Korelasi antara produksi biogas per liter POME yang diinput dilihat berdasarkan periode hari

Dapat dilihat bahwa temperatur sangat berpengaruh nyata pada proses anaerobik untuk mendegradasi bahan organik di dalam limbah cair. Dari grafik tersebut di atas terlihat bahwa temperatur di bawah $45{ }^{\circ} \mathrm{C}$, produksi biogas mengalami penurunan hingga mencapai kurang dari 20 liter biogas per liter POME yang diumpankan.

Adapun pada Gambar 3 menunjukkan bahwa dengan pertambahan hari, kemampuan konversi POME menjadi biogas semakin meningkat. Hal ini bisa disebabkan karena kestabilan reaktor mulai tercapai meski fluktuasi 
temperatur tetap terjadi. Hasil ini juga menekankan bahwa konversi POME menjadi biogas tetap terjadi dengan hasil yang cukup baik meskipun di awal tidak dilakukan perlakuan seperti netralisasi dan penurunan temperatur terlebih dahulu.

Dengan kondisi tersebut di atas, proses penguraian POME menjadi biogas dapat dilakukan tanpa melalui pretreatment. Umpan POME yang mengandung banyak bahan organik dengan kondisi temperatur $45-50{ }^{\circ} \mathrm{C}$, langsung diumpankan ke reaktor fixed bed. Proses ini berhasil dengan baik ditunjukkan dengan keberhasilan produksi biogas sebanyak 25,43 liter per liter POME yang diumpankan. Penurunan temperatur operasi dalam reaktor yang terjadi akibat hujan dan tidak beroperasinya pabrik tidak mengakibatkan seluruh bakteri langsung mati, melainkan hanya penurunan kinerja yang menjadi kurang maksimal, namun setelah itu reaktor masih bisa dioperasikan ketika umpan POME diberikan.

Buku panduan Konversi POME Menjadi Biogas $^{(13)}$, menyebutkan bahwa untuk mengolah POME diperlukan pengaturan temperatur dan $\mathrm{pH}$ sebelum dimasukkan dalam reaktor. Untuk mengontrol $\mathrm{pH}$, biasanya dipergunakan zat kapur, natrium bikarbonat, atau natrium hidroksida. Hal ini hampir sama dengan yang dilakukan oleh Borja $^{(14)}$ dalam penelitiannya, pengolahan POME memerlukan netralisasi dengan menggunakan natrium hidroksida dan temperatur dijaga tetap pada $35^{\circ} \mathrm{C}$.

Namun dalam penelitian ini, netralisasi tidak dilakukan, padahal temperatur berfluktuasi dengan rentang yang cukup luas yaitu $32-56{ }^{\circ} \mathrm{C}$. Hal ini bisa dikarenakan faktor unjuk kerja reaktor unggun tetap yang menjadi kunci, karena jika perlakukan awal ini dihilangkan untuk POME yang diolah dengan jenis reaktor yang lain (covered lagoon atau juga reaktor langka berpengaduk), hasilnya bisa jadi tidak sama.

Sehingga keberhasilan ini dapat mengubah desain pengolahan POME yang ada saat ini. Pengurangan unit pretreatment akan mengurangi biaya investasi baik peralatan dan lahan serta biaya operasi. Penelitian yang dilakukan oleh Murti ${ }^{(15)}$ pretreatment limbah cair POME perlu dilakukan untuk menghilangkan faktor penghambat proses anaerobik seperti temperatur dan netralisasi.

Dalam penelitian ini direncanakan temperatur operasi pada $50-60{ }^{\circ} \mathrm{C}$ namun dengan tanpa pengendalian kondisi input temperatur POME yang masuk ke reaktor berkisar pada $32-56{ }^{\circ} \mathrm{C}$, sehingga reaktor bekerja pada kondisi mesofilik dan termofilik oleh sebab itu diperlukan penelitian lanjutan terkait dengan koloni bakteri yang hidup di dalam reaktor fixed bed ini.

\section{KESIMPULAN}

Proses mikrobiologi pengolahan POME dapat dilakukan dengan menggunakan bakteri anaerobik namun tanpa melalui pretreatment seperti hal yang umum dilakukan untuk menghasilkan biogas. Umpan POME yang mengandung bahan organik dengan kondisi temperatur $45-50{ }^{\circ} \mathrm{C}$, langsung diumpankan ke dalam reaktor fixed bed. Proses ini berhasil dengan baik ditunjukkan dengan keberhasilan produksi biogas 25,43 liter per liter umpan POME. Penggunaan fixed bed reaktor, sangat handal untuk kondisi umpan yang berubah-ubah dan bakteri masih dapat tetap bekerja ditandai dengan masih timbulnya biogas, meskipun kondisi temperatur sempat mengalami penurunan. Proses penguraian POME tanpa melalui pretreatment ini akan mengubah desain pengolahan yang selama ini dilakukan secara signifikan sehingga akan banyak mengurangi biaya investasi dan operasi untuk proses pretreatment. Namun demikian, perlu dilakukan penelitian lanjutan untuk mengetahui jenis koloni bakteri yang ada mengingat kondisi operasi dari kondisi mesofilik dan termofilik.

\section{PERSANTUNAN}

Ucapan terima kasih kami sampaikan kepada Kementerian Riset, Teknologi, dan BRIN atas sumber pendanaan yang diberikan melalui program Insinas. Juga kepada PTPN V Sei Pagar Riau yang telah memberi izin serta mendukung pelaksanaan observasi lapangan hingga terlaksananya penelitian ini. Penghargaan tertinggi kami sampaikan juga kepada para staf PTSEIK BPPT yang tergabung dalam kegiatan flagship biogas POME.

\section{DAFTAR PUSTAKA}

1. Nurrochmat, D. R., Boer, R., Ardiansyah, M., Immanuel, G., \& Purwawangsa, H. (2020). Policy forum: Reconciling palm oil targets and reduced deforestation: Landswap and agrarian reform in Indonesia. Forest Policy and Economics, 119, 102291.

2. Tan, K. T., Lee, K. T., Mohamed, A. R., \& Bhatia, S. (2009). Palm oil: Addressing issues and towards sustainable development. Renewable and Sustainable Energy Reviews, 13(2), 420-427.

3. Hambali, E., \& Rivai, M. (2017). The potential of palm oil waste biomass in Indonesia in 2020 and 2030. In IOP Conference Series: Earth and Environmental Science (Vol. 65, No. 1). IOP Publishing. 
4. Ramaraj, R., \& Unpaprom, Y. (2016). Effect of temperature on the performance of biogas production from Duckweed. Chemistry Research Journal, 1(1), 58-66.

5. Santoso, A. D. (2018). Evaluasi Kinerja Pabrik Kelapa Sawit Dalam Produksi Energi Terbaharukan. Jurnal Teknologi Lingkungan, 19(2), 213-220.

6. Rajani, A., Santosa, A., Saepudin, A., Gobikrishnan, S., \& Andriani, D. (2019). Review on biogas from palm oil mill effluent (POME): challenges and opportunities in Indonesia. In IOP Conference Series: Earth and Environmental Science (Vol. 293, No. 1, p. 012004). IOP Publishing.

7. Choong, Y. Y., Chou, K. W., \& Norli, I. (2018). Strategies for improving biogas production of palm oil mill effluent (POME) anaerobic digestion: A critical review. Renewable and Sustainable Energy Reviews, 82, 2993-3006.

8. Winanti, W. S., Prasetiyadi, P., \& Wiharja, W. (2019). Pengolahan Palm Oil Mill Effluent (POME) menjadi Biogas dengan Sistem Anaerobik Tipe Fixed Bed tanpa Proses Netralisasi. Jurnal Teknologi Lingkungan, 20(1), 143-150.

9. Krakat, N., Westphal, A., Schmidt, S., \& Scherer, P. (2010). Anaerobic digestion of renewable biomass: thermophilic temperature governs methanogen population dynamics. Applied and environmental microbiology, 76(6), 1842-1850.

10. Montgomery, L. F., \& Bochmann, G. (2014). Pretreatment of feedstock for enhanced biogas production (pp. 1-20). Ireland: IEA Bioenergy.

11. Thauer, R. K., Jungermann, K., \& Decker, K. (1977). Energy conservation in chemotrophic anaerobic bacteria. Bacteriological reviews, 41(1), 100.

12. Indriyati, I. (2005). Pengolahan Limbah Cair Organik Secara Biologi Menggunakan Reaktor Anaerobik Lekat Diam. Jurnal Air Indonesia, 1(3).

13. Parinduri, L. (2018). Analisa Pemanfaatan Pome Untuk Sumber Pembangkit Listrik Tenaga Biogas Di Pabrik Kelapa Sawit. JET (Journal of Electrical Technology), 3(3), 180183.

14.Borja, R., \& Banks, C. J. (1994). Anaerobic digestion of palm oil mill effluent using an upflow anaerobic sludge blanket reactor. Biomass and Bioenergy, 6(5), 381389.

15. Murti, G. W., Pertiwi, A., Masfuri, I., Juwita, A. R., Adiprabowo, A. B., Dwimansyah, R., Senda, S. P., \& Prasetyo, D. H. (2019). Ulasan Teknologi Pretreatment Terkini Limbah Cair POME Sebagai Umpan Digester Biogas 